\title{
Socially Responsible Investment: A Comparison between the Performance of Sustainable and Traditional Stock Indexes
}

\author{
José Dias Curto* and Catarina Vital
}

Instituto Universitário de Lisboa (ISCTE-IUL and BRU-UND), Portugal

\begin{abstract}
The doubt about whether socially responsible investment is a viable strategy for investors seeking to maximize both social and financial returns is the central question of this paper. This is addressed by investigating whether portfolio selection based on sustainability criteria harms investor's returns, or in contrast it can be a driver of superior financial benefits. With this purpose, daily prices and returns of 4 traditional and 10 sustainable stock indexes are analyzed from 2001 to 2011 and in the peaks and downs of both bull and bear markets. One of the major results of this study is that sustainable indexes outperform traditional stock indexes in all the periods under analysis; however the differences on average returns are not statistically significant. Through unit root tests we acknowledge that returns are stationary and levels are nonstationary. The short-run relationship analysis based on Granger causality test reveals a feedback effect between traditional and sustainable stock indexes returns. In contrast, long-run relationship, based on cointegration analysis, points that most of the stock indexes are not cointegrated, suggesting that sustainable and traditional stock indexes do not have a long-run linkage and thus can diverge without bound.
\end{abstract}

Keywords: Socially responsible investment, Sustainable stock indexes, financial returns, Long run.

\section{INTRODUCTION}

The combined effect of the financial crises, huge quantity of new data on the consequences of global warming, concerns about water scarcity, human rights and poverty, governance scandals and recent environmental disasters are notably changing the way stakeholders value the integration and management of sustainability related issues as drivers of long-term value (KPMG 2011).

There is a growing evidence (e.g. Lombardo and D'Orio 2012)) that investors are willing to incorporate environmental, social and governance related issues in their investment decisions. These investors seek to maximize financial returns, while doing well for the vast society (Statman and Glushkov 2008; Louche 2004; Eurosif 2008). Such awareness have led to the emergence of sustainability-related indexes linked to financial stock markets (López 2007; Louche 2004; Cortez, Silva, and Areal 2009) and they have been attracting more and more investors.

As a consequence, Sustainable or Socially Responsible Investment (SRI) has been growing at a faster pace than the broader universe of conventional investment assets under management globally (Eurosif 2010; SIF 2010). At the end of September 2010 the global SRI market reached approximately $€ 7.6$ trillion, with Europe holding the largest share $(66 \%)$, followed

*Address correspondence to this author at the Department of Quantitative Methods, ISCTE School of Business, Complexo INDEG/, ISCTE, Av. Prof. Aníbal Bettencourt, 1600-189 Lisboa, Portugal; Tel: 351217826100 ;

Fax: 35121 7938709; E-mail: dias.curto@iscte.pt by the North America (33\%) and Australia, New Zeeland and Japan (1\%) (Eurosif 2010). In Europe, the SRI market is thriving at an incredible pace, having almost doubled since 2008 (Eurosif 2010). The American SRI market is also thriving, having increased around $380 \%$ from 1995 to 2010 , while the broader universe of assets under professional management increased $260 \%$ (SIF2010).

However, the ancient question remains: Are Socially Responsible Investment strategies able to provide superior returns to investors? Or instead, it implies a trade-off between environmental, social and governance concerns and portfolio's financial performance?

Hence, the main objective of this study is to contribute to this field by investigating whether Environmental, Social and Governance (ESG) integration in the portfolio selection harms investor's returns, or in contrast it can be a driver of superior financial benefits. To address this question, daily stock returns of both traditional and sustainable indexes from 2001 to 2011 are firstly compared, followed by the creation of event-windows to analyze the reaction of the two categories of indexes when facing the peaks and downs of both bull and bear markets. Then, short and long term relationships between traditional and sustainable stock indexes are analyzed attempting to capture any common trends among the various stock indexes.

The paper adds to the Sustainable or Socially Responsible Investment (SRI) literature in several important directions. Firstly, a large range of sustainable stock indexes are analyzed (10). The 
sample includes American, European and global sustainable stock indexes. Secondly, besides comparing returns of traditional and sustainable stock indexes throughout all the period in analysis, we also looked for differences in shorter periods of time. These periods were defined according to the economical context (up and down trends in the stock markets). Finally, we test both short and long run relationships among the various stock indexes considering Granger causality test and cointegration analysis, respectively. This fact made our analysis more powerful, once in addition to the previous empirical studies, we are also trying to capture future common trends among the stock indexes.

The paper is organized as follows. Firstly, we present a brief revision of the main empirical contributions of previous studies to the relationship between ESG portfolio integration and its financial benefits. Secondly, we describe the data set and the statistical/econometric methodology. Subsequently, we present the statistical results. Finally, section 4 presents some concluding remarks.

\section{LITERATURE REVIEW}

Previous empirical studies in this area are mainly related with contributions 1 and 2, since they are focused on the relationship between SRI strategies and both corporate and financial markets returns. However, this is not a consensually matter, being an area of much debate among academics and professionals. In fact, previous studies trying to explore the benefits of the integration of ESG factors in investment strategies have produced mixed results.

In order to answer the question posed by Business Week (1999): "Can business meet new social, environmental, and financial expectations and still win?", Orlitzky, Schmidt, and Rynes (2003)conducted a meta-analysis study on the relationship between Corporate Social Performance (CSP) and Corporate Financial Performance (CFP). Based on the 52 quantitative research studies, the authors found a positive correlation between CSP and corporate financial performance. King and Lenox (2001) also identified a positive correlation between environmental performance and financial performance.

Statman (2000), Schröder (2004), Elsayed and Paton (2004), Benson, Brailsford, and Humphrey (2006), Statman (2006), Bauer, Otten, and Rad (2006), Stenström and Thorell (2007), Statman and Glushkov
(2008), Cortez et al. (2009), Machado, Machado, and Corrar (2009) compared the performance of responsible funds/indexes against the performance of conventional funds/indexes and they concluded that differences between the returns are not statistically significant. Machado et al. (2009) argued that the comparable returns of the indexes can be explained by the fact that a significant number of companies are comprised in more than one index at the same time. Statman and Glushkov (2008) referred that the return advantage of the positive screening companies is offset by the return disadvantage from the exclusion of companies from industries as tobacco, alcohol, gambling, firearms, military and nuclear operations.

Stenström and Thorell (2007) also compared the performance of conventional and SRI funds, but they concluded that regular funds outperformed the SRI funds. Then the authors developed a method of evaluating SRI funds by decomposing fund performance into firm level performance and fund management performance, and they found that the replicating portfolios perform better than the regular funds, suggesting that certain socially responsible practices can positively affect fund performance.

López et al. (2007) examined the link between CSR practices and some performance and accounting indicators as ROA, ROE, cost of capital, profit margin of a list of companies belonging to the DJSI and another list with companies on the Dow Jones Global Index (DJGI) but not on the DJSI. The authors found that the relation between above mentioned variables were negative during the first years that CSR practices were adopted. Since the negative short-term effects can inhibit companies to adopt CSR practices, López et al. (2007) argued that government can play a very important role by legislating or giving financial benefits to companies that adopt good practices.

Curran (2003) conducted an event study to determine the effect of CSR in share price by measuring the effects of inclusion and deletion of the FTSE4 Good in the companies' share price. Results showed a positive trend in share prices in announcement cases and a negative trend when facing a deletion to the index, but results were not statistically significant. According to the authors, one reason to this situation is that in the period analyzed these kinds of indexes were not very known and therefore were not considered by many investors and analysts as leading indexes for making investment decisions. 
Ziegler, Schröder, and Rennings (2007) examined the effect of environmental and social concerns on the stock performance of European companies based on the Capital Asset Pricing Model (CAPM) and on the multifactor model according to Fama and French. While cross-sectional regressions showed that environmental concerns positively affect stock return, the social concerns have a significantly negative effect in stock returns. While the traditional CAPM considers only the return of the market portfolio to explain the returns of a portfolio or stock, the Fama and French model includes two additional factors: the Small (market capitalisation) Minus Big (SMB) and the High (book-to-market ratio) Minus Low (HML), measuring the historic excess returns of small over big caps and of value stocks over growth stocks, respectively.

Velde, Vermeir, and Corten (2005) compared the alphas of four constructed sustainability ratings groups: 'best', 'good', 'bad' and 'worst'. The authors concluded that although the alpha results were not statistically significant, sustainable rating had a positive impact on alphas over the period under analysis.

To investigate whether SRI transcends market cycles and style preferences, Abramson and Chung (2000) created two separate portfolios (one on a rebalancing strategy and other on a buy-and-hold strategy). The portfolio creation was based on ranking stocks within the Domini Social Index (DSI) by relative yield and relative market capitalisations-to-revenues at different points. The overall conclusion was that SRI strategies can provide competitive returns relative to benchmark to both value and growth style investment managers.

In order to support the idea that the incorporation of environmental concerns in the investment strategy provides financial benefits Derwall et al. (2005) compared the performance of a portfolio constructed of 'eco-efficient' companies' stocks with the conventional ones. Based on portfolio measures as CAPM and multi-factor model frameworks, the authors found that environmental responsible portfolios can provide superior returns.

Hong and Kacperczyk (2009), Chong, Her, and Phillips (2006), Hume and Larkin (2008) and Shank, Manullang, and Hill (2005) focused their studies by comparing the performance of SRI stocks against 'sin stocks'1. While Hong and Kacperczyk (2009), Chong et al. (2006), Hume and Larkin (2008) concluded that 'sin stocks' outperform comparable, Shank et al. (2005) argued that the selection of stocks of companies with higher sustainability standards may represent a valuemaximizing strategy with superior risk-adjusted earnings potential.

In terms of quantitative techniques, correlation and regression analyses are the most commonly used in previous SRI empirical research. This paper adds to previous investigation by also employing the Granger causality test and cointegration analysis. While Granger causality test is employed to test for shortterm relationships among stock indexes returns, the cointegration analysis is used to detect nonspurious relationships between the levels of both traditional and sustainable stock indexes.

\section{EMPIRICAL ANALYSIS}

\subsection{Data and Sample Selection}

Previous studies used data on socially responsible mutual funds, socially responsible indexes, 'sin stocks', stocks with good and bad environmental records, and stocks with good and bad community or employee relations. According to Statman and Glushkov (2008) comparing stock indexes of socially responsible companies against conventional stock indexes provide a better and unbiased understanding of the relationship between stock returns, once comparisons are not confounded by management skills and expenses. Hence, this study intends to compare the benefits of sustainable investment by comparing the performance of the traditional stock indexes against the performance of the sustainable ones.

As noted before, most of the studies are focused on the US SRI market and just a few on the European market. In this investigation our purpose is to extend previous researches by analyzing stock indexes that capture sustainability leaders in Europe, North America and worldwide. The indexes chosen to analyze are showed in the following table:

Among these are the Dow Jones Sustainability Indexes Family, the FTSE4 Good Indexes, the MSCI

\footnotetext{
"'Sin stocks", also called as "socially irresponsible stocks", are stocks of companies that provide goods or services that the society claims as unethically, being generally associated with industries like tobacco, alcohol, pornography, gambling, armaments, or nuclear power.
} 
Table 1: Nature and Geographical Area of Stock Indexes Analyzed

\begin{tabular}{|c|c|c|c|c|c|}
\hline \multirow[b]{2}{*}{ Stock Index } & \multicolumn{2}{|c|}{ Nature of the Index } & \multicolumn{3}{|c|}{ Geographical area covered } \\
\hline & Traditional Index & Sustainable Index & Europe & $\begin{array}{l}\text { USA/ North } \\
\text { America }\end{array}$ & Global \\
\hline Calvert Social Index (Calvert) & & $\sqrt{ }$ & & $\sqrt{ }$ & \\
\hline $\begin{array}{l}\text { Dow Jones Sustainability Index (DJSI) } \\
\text { Europe }\end{array}$ & & & $\sqrt{ }$ & & \\
\hline DJSI North America (DJSI NA) & & $\sqrt{ }$ & & $\sqrt{ }$ & \\
\hline DJSI United States (DJSI U.S.) & & $\sqrt{ }$ & & $\sqrt{ }$ & \\
\hline DJSI World & & $\sqrt{ }$ & & & $\sqrt{ }$ \\
\hline DJSI World ex U.S. & & $\sqrt{ }$ & & & $\sqrt{ }$ \\
\hline EURO STOXX Sustainability & & $\sqrt{ }$ & $\sqrt{ }$ & & \\
\hline EURO STOXX & $\sqrt{ }$ & & $\sqrt{ }$ & & \\
\hline $\begin{array}{l}\text { Financial Times Stock Exchange } 100 \\
\text { (FTSE 100) }\end{array}$ & $\sqrt{ }$ & & $\sqrt{ }$ & & \\
\hline FTSE4Good Europe Index (FTSE4Good E) & & $\sqrt{ }$ & $\sqrt{ }$ & & \\
\hline FTSE4Good Global Index (FTSE4Good G) & & $\sqrt{ }$ & & & \\
\hline $\begin{array}{l}\text { Morgan Stanley Capital International } \\
\text { (MSCI World) }\end{array}$ & $\sqrt{ }$ & & & & \\
\hline MSCI KLD 400 Social Index & & $\sqrt{ }$ & & & $\sqrt{ }$ \\
\hline Standard \& Poor's 500 (S\&P 500) & $\sqrt{ }$ & & & $\sqrt{ }$ & \\
\hline
\end{tabular}

KLD 400 Social Index, the Calvert Social Index and the EuroStoxx Sustainability Indexes, that have been developed by organizations of recognized prestige. The rationale of these indexes is that sustainability practices will benefit companies and shareholders in the long run.

Thus, for the performance analysis conducted in this study, daily last prices not adjusted for dividends has been collected for both traditional and sustainable stock indexes during the period from November 19, 2001 (the first trading day of the newest stock index: FTSE4 Good Global) to March 31, 2011, yielding a total of 2,444 observations. Data was gathered from Bloomberg.

\subsection{Statistical and Econometric Methodology}

As noted before, this empirical study aims to analyze the linkage between SRI strategies and investor's financial performance. To achieve this objective we examine whether investing in responsible stock indexes provides financial benefits or at least it does not harm investors' returns. Thus, the objectives of the present study are: (1) To compare the performance of the traditional stock indexes against the performance of the sustainable stock indexes. (2) To analyze short-term dependences among traditional and sustainable stock indexes returns. (3) To capture long run relationships between traditional and sustainable stock indexes.

The empirical research carried out on this paper is conducted by using the following statistical and econometric tools: ANOVA and Kruskall-Wallis tests to answer the question related with (1): 'Are sustainable Stock Indexes providing superior returns to investors?'. Unit Root tests (ADF and KPSS) are used as a prerequisite for testing short and long term relationships among stock indexes (2 and 3). Granger causality test is employed to accomplish (2): 'Does traditional stock indexes returns influence the behavior of sustainable stock indexes, and vice versa?'. Finally, cointegration analysis is used to answer the question: 'Have traditional and sustainable stock indexes common trends in the future?' related with objective (3). For details on Unit Root tests, Granger causality test and Cointegration see, for example, Maddala and Kim (2000).

\section{RESULTS}

\subsection{Statistical Properties of Prices and Returns}

To summarize the statistical properties of prices (levels) and returns, after graphing the prices and the 


\section{TraditionalStock Indexes daily prices}
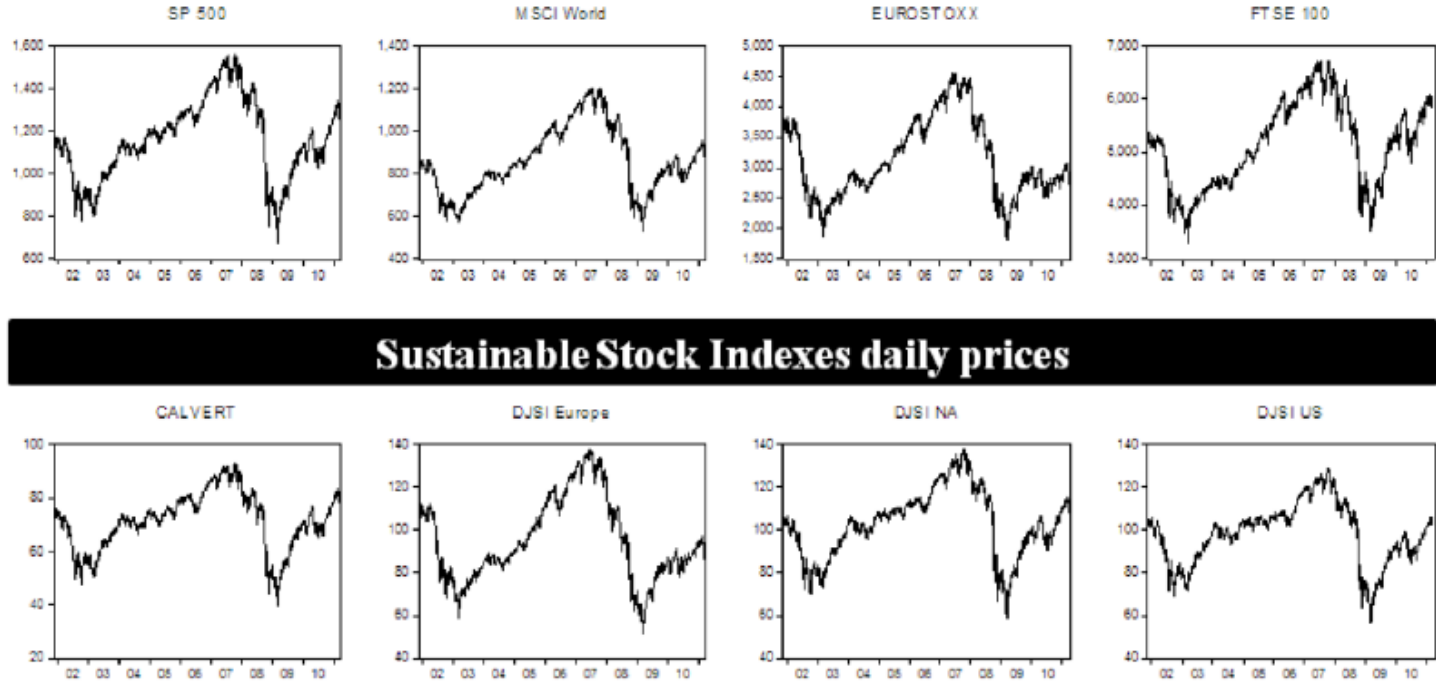

\section{SustainableStock Indexes daily prices}
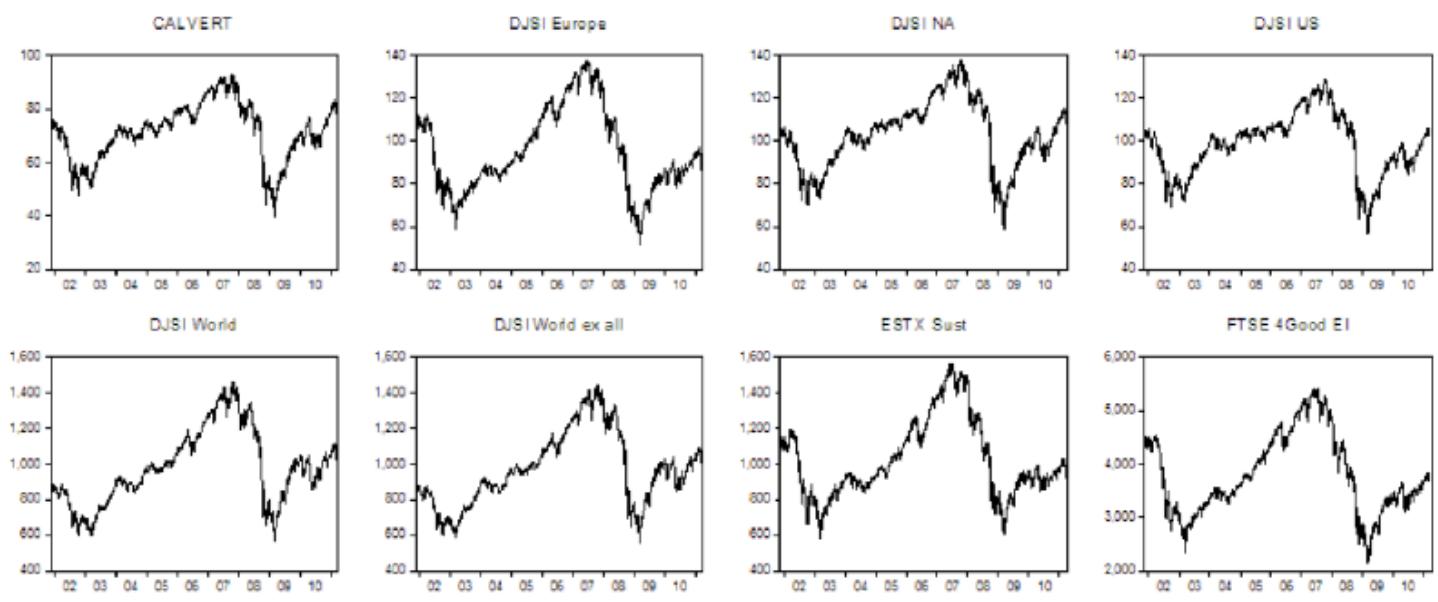

Dus I Worid ex all
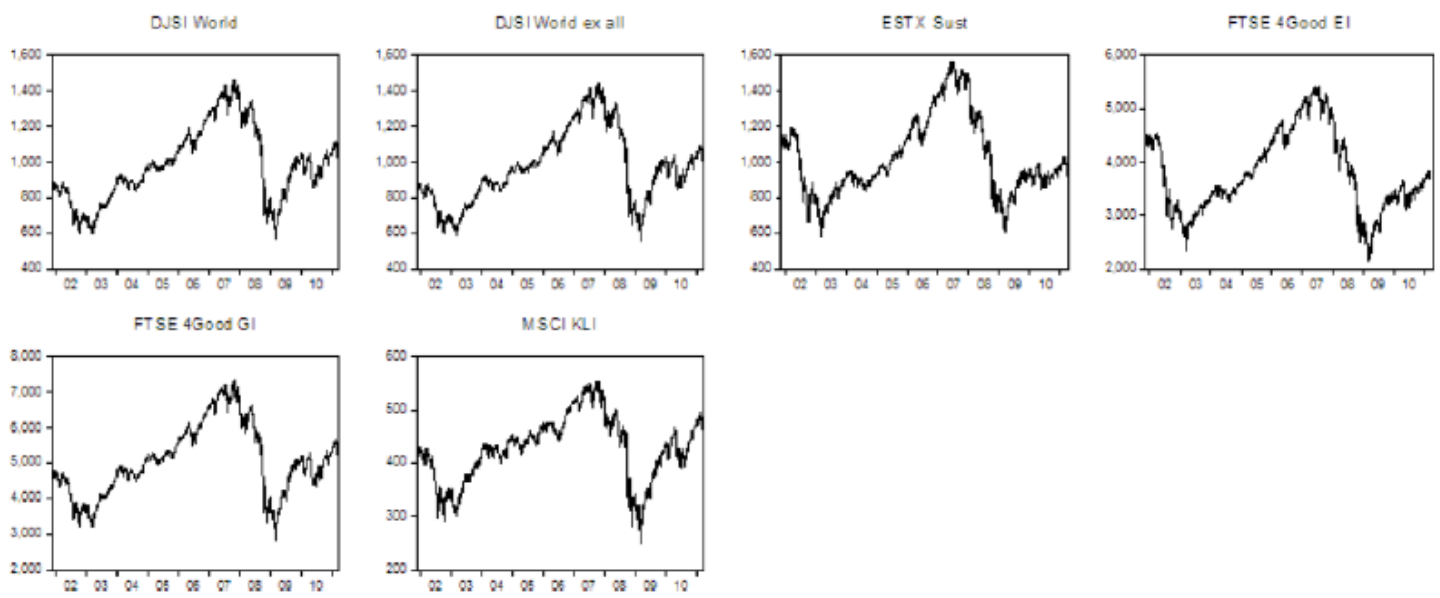

$M S C I ~ K L I$

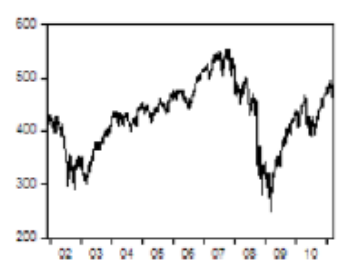

Figure 1: Stock indexes daily prices (levels).

series of returns, visual inspection is done. Then, relevant descriptive statistics for returns are computed (including the Jarque-Bera normality test).

Regarding visual inspection, Figure 1 plots the stock indexes daily closing values of both traditional and sustainable stock indexes from November 19, 2001 to March 31, 2011:

As one can see, stock indexes daily prices (levels) are characterized by various increasing and decreasing trends, therefore we expect they are nonstationary ${ }^{2}$ time series. Levels plots also allow us to identify two bullish (periods in which an increasing trend is verified) and two bearish markets (periods in which a decreasing trend is verified) during the period under

analysis. Table 2 shows the proxy dates (for the S\&P 500 ) when both bull and bear markets started:

Table 2: Maximum and Minimum Values of S\&P 500

\begin{tabular}{|c|c|c|}
\hline Maximum/ Minimum values & Date & Last value \\
\hline \hline Maximum 1 & 24.03 .2000 & 1527.46 \\
\hline Minimum 1 & 23.07 .2002 & 797.7 \\
\hline Maximum 2 & 19.06 .2007 & 1533.7 \\
\hline Minimum 2 & 09.03 .2009 & 676.53 \\
\hline
\end{tabular}

Thus, the identification of maximum and minimum values of S\&P 500 daily prices allow us to establish the periods that will be used to test whether traditional and sustainable stock indexes have the same reaction in 'good and bad times'. Figure 2 denotes the 3 periods that will support our analysis: 


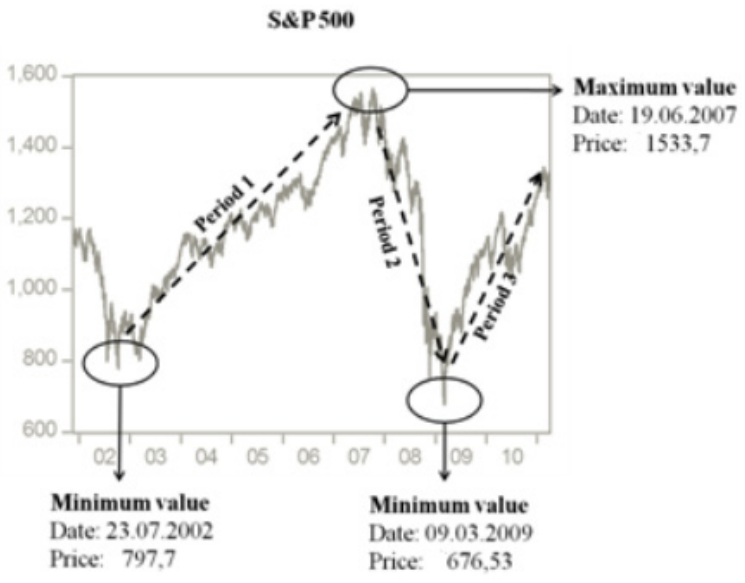

Figure 2: Sub-periods under analysis.
In order to analyze stock indexes returns, the continuously compounded percentage rates of return are computed by taking the first differences of the logarithm of series (where $P_{j t}$ is the daily closing value for each stock index $j$ at time $t$ ):

$r_{j t}=100\left[\ln \left(P_{j t}\right)-\ln \left(P_{j t-1}\right)\right]$,

Figure 3 presents the daily returns for all the stock indexes under analysis:

Despite the pronounced volatility clustering reflecting, among others things, the world stock markets crises, it is possible to conclude that returns

\section{TraditionalStock Indexes daily returns}

SP 500ret

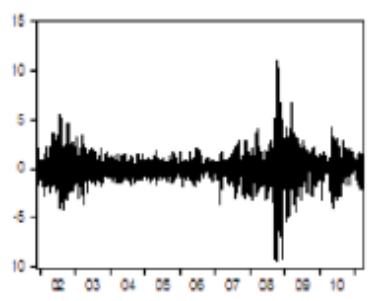

MSCI Worldret:

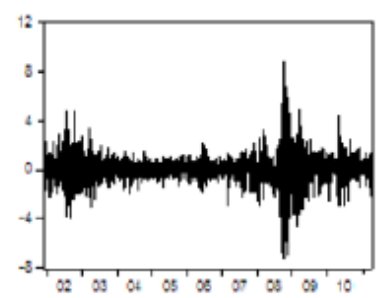

EUROSTOXOKRET

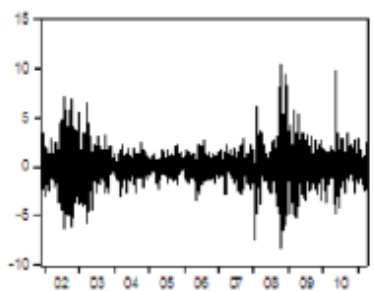

FTSE 100ret

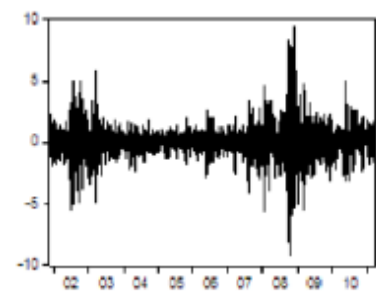

\section{SustainableStock Indexes daily returns}

CALVERTRET

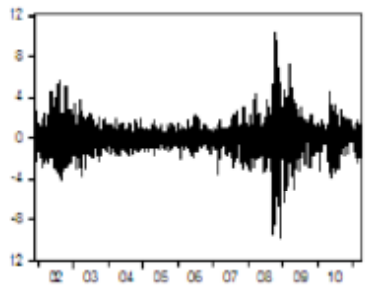

D.SI World ex alliret

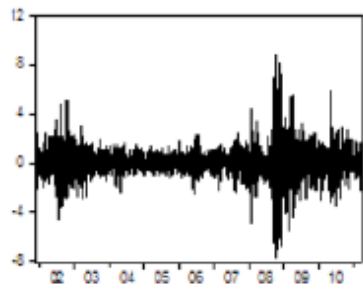

FTSE 4Good Giret

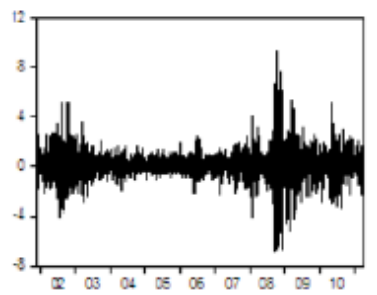

DJSI Europeret

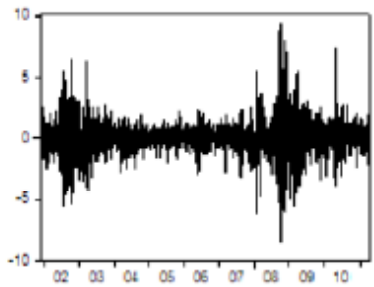

DJaI Worldre:

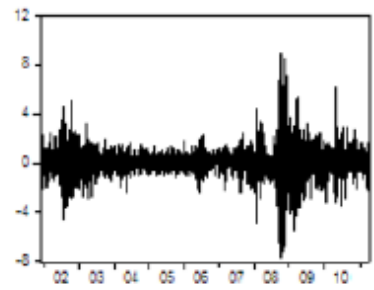

MSCI HLiret

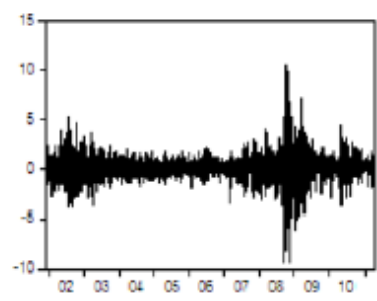

DJSI NAVE:

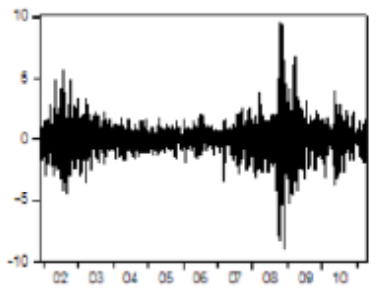

ESTX Sustre:

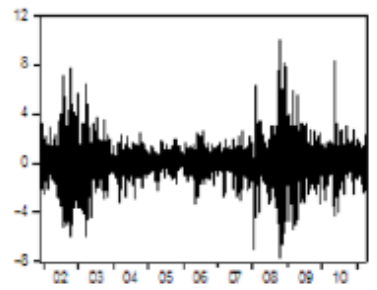

DJSI USret

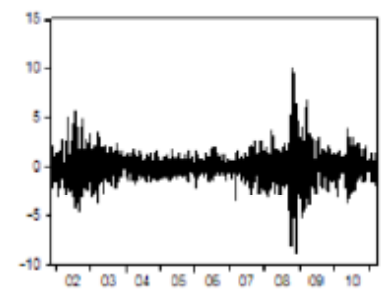

FTSE 46ood Elret

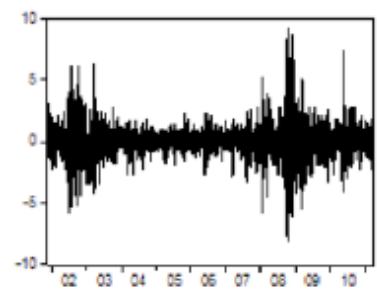

Figure 3: Stock indexes daily returns. 
Table 3: Descriptive Statistics

\begin{tabular}{|c|c|c|c|c|c|c|c|c|c|c|}
\hline & Stock Index returns & Mean & Median & Max & Min & Std Dev & Skewness & Kurtosis & Jarque-Bera & P-value \\
\hline \multirow{4}{*}{ 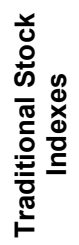 } & SP_500 & 0.00579 & 0.03908 & 10.957 & -9.470 & 1.339 & -0.149 & 12.411 & 9025.09 & 0 \\
\hline & MSCI_WORLD & 0.00340 & 0.05885 & 8.720 & -7.156 & 1.073 & -0.259 & 11.219 & 6903.21 & 0 \\
\hline & EUROSTOXX & -0.01086 & 0.00000 & 10.438 & -8.208 & 1.562 & 0.096 & 8.465 & 3043.70 & 0 \\
\hline & FTSE_100 & 0.00416 & 0.00000 & 9.384 & -9.265 & 1.300 & -0.103 & 10.356 & 5511.72 & 0 \\
\hline \multirow{10}{*}{ 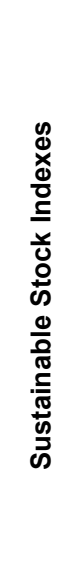 } & CALVERT & 0.00430 & 0.02715 & 10.381 & -9.880 & 1.393 & -0.097 & 10.661 & 5977.87 & 0 \\
\hline & DJSI_EUROPE & -0.00861 & 0.03980 & 9.294 & -8.524 & 1.379 & -0.019 & 8.949 & 3602.25 & 0 \\
\hline & DJSI_NA & 0.00343 & 0.04960 & 9.448 & -9.002 & 1.285 & -0.187 & 11.363 & 7132.67 & 0 \\
\hline & DJSI_US & 0.00007 & 0.02563 & 10.229 & -8.828 & 1.296 & -0.050 & 11.283 & 6984.50 & 0 \\
\hline & DJSI_WORLD_EX_US & 0.00882 & 0.04085 & 8.814 & -7.634 & 1.218 & -0.229 & 10.941 & 6441.12 & 0 \\
\hline & DJSI_WORLD & 0.00955 & 0.04266 & 8.838 & -7.775 & 1.218 & -0.220 & 11.084 & 6671.69 & 0 \\
\hline & ESTX_SUST & -0.00632 & 0.00000 & 10.018 & -7.686 & 1.512 & 0.088 & 8.006 & 2553.80 & 0 \\
\hline & FTSE_4GOOD_E & -0.00867 & 0.02304 & 9.228 & -8.212 & 1.381 & -0.007 & 8.926 & 3574.85 & 0 \\
\hline & FTSE_4GOOD_G & 0.00674 & 0.04926 & 9.339 & -6.884 & 1.173 & -0.122 & 10.699 & 6040.22 & 0 \\
\hline & MSCI_KLD & 0.00575 & 0.01524 & 10.380 & -9.353 & 1.334 & -0.059 & 11.372 & 7136.18 & 0 \\
\hline
\end{tabular}

seem to be stationary, once they are stable around a constant level.

In order to acknowledge the main stock indexes returns' statistical properties, relevant descriptive statistics were computed and are shown in Table 3.

As the previous table shows, returns means of the various stock indexes are almost all positive, but very close to zero. However, it is important to note that, in the period under analysis, the returns mean of the sustainable indexes are higher than the returns mean of the traditional indexes $(0.001506$ and 0.000623 , respectively).

Regarding risk, once the standard deviations of all indexes are very near from each other, we can also conclude that sustainable and traditional stock indexes have similar levels of risk.

The kurtosis for all the stock indexes is higher than the expected value for a standard Gaussian distribution which is 3 , showing the fat tails stylized fact of these type of empirical distributions. Additionally, the JarqueBera normality tests are far beyond the critical value, indicating that the Gaussian distribution hypothesis for all the empirical return distributions should be clearly rejected (another stylized fact of financial returns).

\subsection{Statistical and Econometric Analyses}

\section{Comparison between Stock Indexes Performance}

As stated before, to know whether investing in sustainable stock indexes is more profitable than investing in traditional stock indexes, we performed the Analysis of Variance (ANOVA) test. The main purpose is to check if the difference in the returns' sample means from traditional and sustainable stock indexes are statistically significant or not. Then, to prevent the conclusions of this study against the possibility of not matching ANOVA's assumptions, a nonparametric test (Kruskall-Wallis) is also computed.

According to the objectives of this study, we expect a statistically higher mean return for the sustainable stock indexes or, at least, a non-statistically difference between the returns of the two types of stock indexes.

The results of ANOVA and Kruskall-Wallis tests are as follows:

Table 4: ANOVA and Kruskal-Wallis Tests

\begin{tabular}{|c|c|c|c|}
\hline \multicolumn{2}{|c|}{ ANOVA } & \multicolumn{2}{c|}{ KRUSKAL-WALLIS } \\
\hline F- test & Sig. & Test & Sig. \\
\hline \hline 0.046 & 1.000 & 1.800 & 1.000 \\
\hline
\end{tabular}

Note: In the Null we state that returns means (ANOVA)/distributions (K-W) of traditional and sustainable stock indexes are equal. 
According to the results of the previous table, both ANOVA (which compares the return means of the stock indexes) and Kruskall-Wallis (which compares the empirical distribution of the stock indexes) tests lead us to do not reject the null. Thus, based on the considered samples, we can assume that the differences among the returns means of the 14 stock indexes are not statistically significant during the period from November 19, 2001 to March 31, 2011.

Next, in order to test for differences according to the economical context (the second goal of this study), ANOVA and Kruskal-Wallis tests are also employed to the 3 specific sub-periods noted before (Figure 2 and Table 5).

Table 5: ANOVA and Kruskal-Wallis Tests (3 Sub-Period Analysis)

\begin{tabular}{|c|c|c|c|c|}
\hline \multirow{2}{*}{ Periods } & \multicolumn{2}{|c|}{ ANOVA } & \multicolumn{2}{c|}{ KRUSKAL-WALLIS } \\
\cline { 2 - 5 } & F- test & Sig. & Test & Sig. \\
\hline \hline Period 1 & 0.060 & 1.000 & 1.135 & 1.000 \\
\hline Period 2 & 0.055 & 1.000 & 2.794 & 0.999 \\
\hline Period 3 & 0.036 & 1.000 & 3.483 & 0.996 \\
\hline
\end{tabular}

Note: In the Null we state that returns means (ANOVA)/distributions (K-W) of traditional and sustainable stock indexes are equal.

Tests comparing stock indexes means and empirical distributions state that the null hypothesis cannot be rejected, thus the main conclusions remain the same. In fact, despite the considered sub-periods (increasing trend or decreasing trend periods), the observed differences among the returns of the 14 stock indexes are not statistically significant.

To overcome possible distortions due to the fact that the larger is the window the weaker will be peaks and downs effects, the next step is to compare stock returns differences considering a 40, 20 and 10 day window around the highest and lower values of the S\&P 500 stock index. The objective is to test whether traditional and sustainable stock indexes behave differently when the stock markets are in the top of a bull or in the bottom of a bear market.

The following tables present the results of a 40, 20 and 10 days window, respectively:

As one can see, with a 20 and a 10 days window there are little increases on test values, but the decision remains the same. Therefore, we can conclude that traditional and sustainable indexes provide comparable returns in spite of the economical context.
Table 6: ANOVA and Kruskal-Wallis Tests (40 Days Window)

\begin{tabular}{|c|c|c|c|c|}
\hline \multirow{2}{*}{ Periods } & \multicolumn{2}{|c|}{ ANOVA } & \multicolumn{2}{c|}{ KRUSKAL-WALLIS } \\
\cline { 2 - 5 } & F- test & Sig. & Test & Sig. \\
\hline \hline July 23, 2002 & 0.011 & 1.000 & 0.323 & 1.000 \\
\hline June 19, 2007 & 0.064 & 1.000 & 1.080 & 1.000 \\
\hline March 9, 2009 & 0.028 & 1.000 & 0.542 & 1.000 \\
\hline
\end{tabular}

Note: the 40 days window is centered on the column 1 dates.

Table 7: ANOVA and Kruskal-Wallis Tests (20 Days Window)

\begin{tabular}{|c|c|c|c|c|}
\hline \multirow{2}{*}{ Periods } & \multicolumn{2}{|c|}{ ANOVA } & \multicolumn{2}{c|}{ KRUSKAL-WALLIS } \\
\cline { 2 - 5 } & F- test & Sig. & Test & Sig. \\
\hline \hline July 23, 2002 & 0.099 & 1.000 & 1.971 & 1.000 \\
\hline June 19, 2007 & 0.033 & 1.000 & 1.076 & 1.000 \\
\hline March 9, 2009 & 0.070 & 1.000 & 0.998 & 1.000 \\
\hline
\end{tabular}

Note: the 20 days window is centered on the column 1 dates.

Table 8: ANOVA and Kruskal-Wallis Tests (10 Days Window)

\begin{tabular}{|c|c|c|c|c|}
\hline \multirow{2}{*}{ Periods } & \multicolumn{2}{|c|}{ ANOVA } & \multicolumn{2}{c|}{ KRUSKAL-WALLIS } \\
\cline { 2 - 5 } & F- test & Sig. & Test & Sig. \\
\hline \hline July 23, 2002 & 0.060 & 1.000 & 0.847 & 1.000 \\
\hline June 19, 2007 & 0.103 & 1.000 & 0.743 & 1.000 \\
\hline March 9, 2009 & 0.063 & 1.000 & 0.790 & 1.000 \\
\hline
\end{tabular}

Note: the 10 days window is centered on the column 1 dates.

Thus, we cannot affirm that investing in sustainable stock indexes provide superior returns to investors. However, it is also important to note that the findings of this study also implies that investing in sustainable indexes does not prejudice shareholders' returns, what contradicts the perception of the existence of a tradeoff between Corporate Social Responsibility (CSR) and Financial Performance as is stated by Derwall et al (2005).

\section{Unit Root Tests and Non-Stationarity}

The results of the ADF and KPSS tests are presented below:

Based on the previous table, while the ADF unit root hypothesis is not rejected, the KPSS stationarity hypothesis is rejected at standard significance levels for all the series of logarithm of prices (levels). Indeed, it is possible to conclude that both traditional and sustainable stock indexes prices (in natural logarithms) are nonstationary. 
Table 9: Unit Root Tests (ADF and KPSS)

\begin{tabular}{|c|c|c|c|c|c|c|}
\hline \multirow{3}{*}{ STOCK INDEXES } & \multicolumn{3}{|c|}{ LOG_PRICES } & \multicolumn{3}{|c|}{ RETURNS } \\
\hline & \multicolumn{2}{|c|}{ ADF } & \multirow{2}{*}{$\begin{array}{c}\text { KPSS } \\
\text { Statistic }\end{array}$} & \multirow{2}{*}{$\begin{array}{c}\text { ADF } \\
\text { Statistic }\end{array}$} & \multirow[b]{2}{*}{ Lag } & \multirow{2}{*}{$\begin{array}{c}\text { KPSS } \\
\text { Statistic }\end{array}$} \\
\hline & Statistic & Lag & & & & \\
\hline SP_500 & $-1.5657^{a}$ & 2 & $0.7628^{\star^{a}}$ & $-39.6281^{* \mathrm{~b}}$ & 1 & $0.0998^{b}$ \\
\hline MSCI_WORLD & $-1.4339^{a}$ & 2 & $0.8646^{\star^{a}}$ & $-36.1591^{\star^{b}}$ & 1 & $0.1160^{b}$ \\
\hline FTSE_100 & $-2.0163^{a}$ & 4 & $0.6379^{*^{a}}$ & $-23.7606^{\star^{\mathrm{b}}}$ & 4 & $0.0848^{b}$ \\
\hline EUROSTOXX & $-1.7560^{a}$ & 1 & $0.8030^{* a}$ & $-51.8424^{* b}$ & 0 & $0.1241^{b}$ \\
\hline CALVERT & $-1.7195^{a}$ & 2 & $0.6575^{\star^{a}}$ & $-38.9198^{\star b}$ & 1 & $0.0991^{b}$ \\
\hline DJSI_EUROPE & $-1.6406^{a}$ & 0 & $0.7864^{\star a}$ & $-23.7150^{* \mathrm{~b}}$ & 4 & $0.1451^{b}$ \\
\hline DJSI_NA & $-1.6003^{a}$ & 2 & $0.7474^{\star^{a}}$ & $-39.0671^{*^{b}}$ & 1 & $0.0985^{b}$ \\
\hline DJSI_US & $-1.6477^{a}$ & 2 & $0.7440^{* a}$ & $-39.6005^{\star b}$ & 1 & $0.0966^{b}$ \\
\hline DJSI_WORLD & $-1.5624^{a}$ & 1 & $0.8486^{* a}$ & $-35.5113^{*^{b}}$ & 1 & $0.0988^{b}$ \\
\hline DJSI_WORLD_EX_US & $-1.5691^{a}$ & 1 & $0.8535^{\star a}$ & $-35.4339^{* b}$ & 1 & $0.0964^{b}$ \\
\hline ESTX_SUST & $-1.6560^{a}$ & 0 & $0.7946^{* a}$ & $-50.6775^{\star^{\mathrm{b}}}$ & 1 & $0.1112^{b}$ \\
\hline FTSE_4GOOD_E & $-1.6955^{a}$ & 0 & $0.7792^{* a}$ & $-23.9774^{* b}$ & 4 & $0.1406^{b}$ \\
\hline FTSE_4GOOD_G & $-1.4658^{a}$ & 2 & $0.8739^{* a}$ & $-35.5055^{\star b}$ & 1 & $0.0980^{b}$ \\
\hline MSCI_KLD & $-1.7343^{a}$ & 2 & $0.6948^{* a}$ & $-39.4531^{* b}$ & 1 & $0.0856^{b}$ \\
\hline
\end{tabular}

${ }^{a}$ Trend and intercept, ${ }^{\mathrm{b}}$ Intercept; *Significant at $5 \%$ level; ADF critical values at the $5 \%$ level: $-3.412^{\mathrm{a}},-2.823^{\mathrm{b}} ; \mathrm{KPSS}$ critical values at $5 \%$ level: $0.146^{\mathrm{a}}$, $0.463^{\mathrm{b}}$.

On the other hand, when returns are considered, the ADF null hypothesis of a unit root is strongly rejected while the KPSS null of stationarity is not rejected. Thus we conclude that both traditional and sustainable stock indexes returns series are stationary.

The conclusions are consistent in both ADF and KPSS tests. Hence, we can conclude that the logarithm of prices are integrated of order 1, I(1), while the returns series are $\mathrm{I}(0)$. Based on these findings, it is possible to conclude that all stock indexes analyzed (in natural logs) are first-difference stationary, and thus proceed with Granger causality and cointegration tests.

\section{Who does 'Granger Cause'? Traditional or Sustainable Stock Indexes?}

In order to test for short-term relationships between stock indexes (i.e. to check whether traditional stock indexes influence sustainable stock indexes and viceversa) Granger causality test is performed.

\section{Traditional Stock Indexes Granger-Cause Sustainable Stock Indexes}

We first analyze if traditional stock indexes returns Granger cause the sustainable stock indexes returns, by assuming in the null that traditional stock indexes 'do not Granger cause' sustainable stock indexes.

Table 10: Probability Associated with the Granger Causality Test

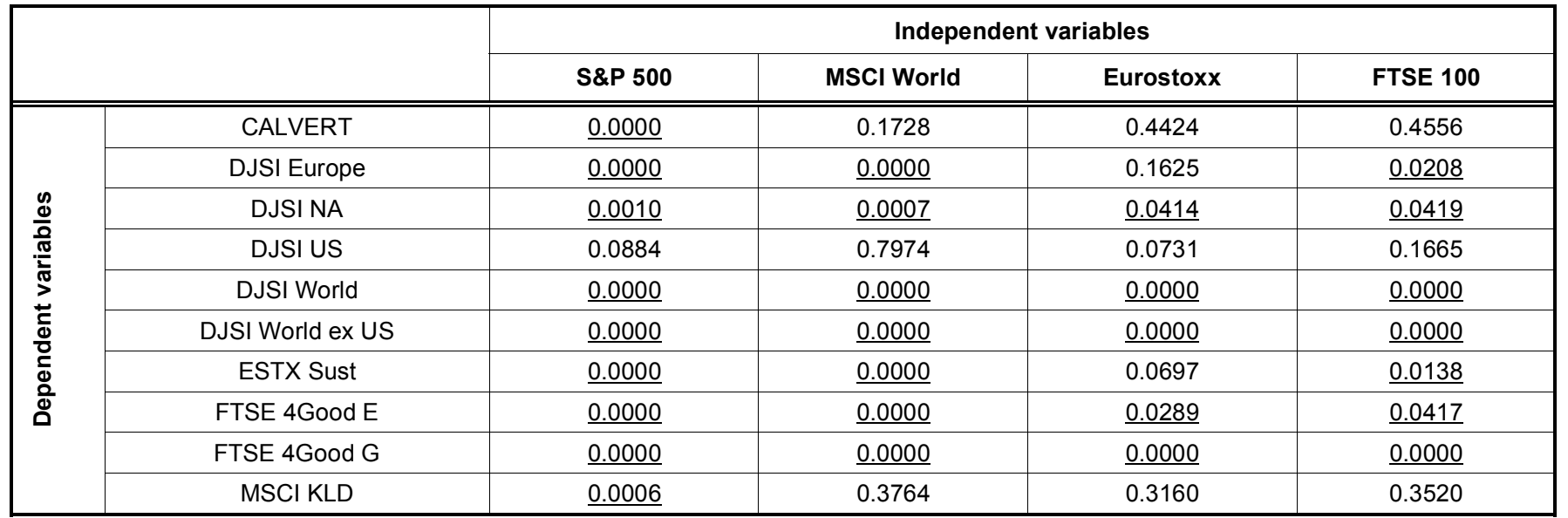

Note: In the Null we state that traditional stock indexes (in column) does not Granger cause sustainable stock indexes (in row). 
The significances associated with Granger test results (with 2 lags) are shown in the next table, where statistically significant Granger causality effects are highlighted:

Based on the significance associated with the Granger test we reject the null and we can conclude that S\&P500 Granger-cause all the sustainable stock indexes at a $1 \%$ significance level (the exception is the DJSI US in which the causality effect is only statistically significant at a $10 \%$ significance level). As the lag for the Granger test is 2, we conclude that S\&P 500 returns from time $t-1$ and $t-2$ impact on the sustainable stock indexes return at time $t$. MSCI World is the second traditional index that Granger-cause a larger number of sustainable stock indexes: 7 .

Thus, we conclude that sustainable stock indexes are strongly dependent from traditional stocks performance, which reinforces the conclusions about the comparable returns between the two categories of stock indexes.

\section{Sustainable Stock Indexes Granger-Cause Traditional Stock Indexes}

Next we test if sustainable stock indexes Grangercause traditional stock indexes returns. Table 11 shows the significance associated with the Granger test values:

As one can see, once the null is rejected in most of cases, it is also possible to conclude that most of traditional stock indexes returns are also Granger caused by the sustainable stock indexes.
The most 'independent' traditional stock index is the American S\&P 500, being only caused by 4 of the 10 sustainable stock indexes analyzed (at a $5 \%$ significance level). Thus, it seems that there is a feedback effect between traditional and sustainable stock indexes.

\section{Stock Indexes Cointegration}

The last goal of this study is to acknowledge whether traditional and sustainable stock indexes are somewhat related in the long-term. Once there are common stocks in both types of indexes, our expectation is that stock indexes series are cointegrated revealing a long-run dependency.

According to Granger and New bold (1974), the use of correlation to measure the long-term relationship between non-stationary time series can lead to the risks of conducting spurious regressions. These alerts led a lot of researchers to transform integrated time series into stationary data, before their inclusion in the regression models, as suggested by Box and Jenkins (1970). The attempt to overcome this constraint has led in practice to the estimation of models that include only variables in differences (the Granger causality was tested based on log differences). However, the stationarity as a pre-requisite for regression analysis creates a model without long-run properties (in levels) and ignores the potential equilibrium relationships suggested by the economic theory.

Thus, by applying the Johansen's (1995) procedure, the next step in this empirical work is to check whether each one of the sustainable stocks index is cointegrated with each one of the traditional stock

Table 11: Probability associated with the Granger Causality Test

\begin{tabular}{|c|c|c|c|c|c|}
\hline & & \multicolumn{4}{|c|}{ Dependent variables } \\
\hline & & S\&P 500 & MSCI World & Eurostoxx & FTSE 100 \\
\hline \multirow{10}{*}{ 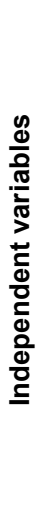 } & CALVERT & $\underline{0.0001}$ & $\underline{0.0000}$ & $\underline{0.0000}$ & $\underline{0.0000}$ \\
\hline & DJSI Europe & 0.1516 & $\underline{0.0034}$ & 0.1356 & 0.0763 \\
\hline & DJSI NA & $\underline{0.0000}$ & $\underline{0.0000}$ & $\underline{0.0000}$ & $\underline{0.0000}$ \\
\hline & DJSI US & 0.2958 & $\underline{0.0000}$ & $\underline{0.0000}$ & $\underline{0.0000}$ \\
\hline & DJSI World & $\underline{0.0001}$ & $\underline{0.0000}$ & $\underline{0.0000}$ & $\underline{0.0000}$ \\
\hline & DJSI World ex US & 0.0592 & 0.3082 & $\underline{0.0000}$ & $\underline{0.0000}$ \\
\hline & ESTX Sust & 0.0541 & $\underline{0.0122}$ & 0.0823 & $\underline{0.0085}$ \\
\hline & FTSE 4Good E & 0.1573 & $\underline{0.0031}$ & 0.0659 & 0.2267 \\
\hline & FTSE 4Good G & 0.0992 & 0.3370 & $\underline{0.0000}$ & $\underline{0.0000}$ \\
\hline & $\mathrm{MSCl} \mathrm{KLD}$ & $\underline{0.0035}$ & $\underline{0.0000}$ & $\underline{0.0000}$ & $\underline{0.0000}$ \\
\hline
\end{tabular}

Note: In the Null we state that sustainable stock indexes (in row) does not Granger cause traditional stock indexes (in column). 


\begin{tabular}{|c|c|c|c|c|c|c|c|c|c|c|c|c|c|c|c|c|c|c|c|c|}
\hline 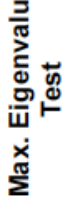 & 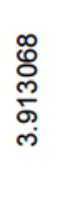 & 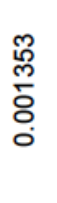 & $\begin{array}{l}\infty \\
\stackrel{0}{0} \\
\& \\
\stackrel{0}{0} \\
\dot{0}\end{array}$ & 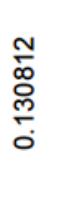 & 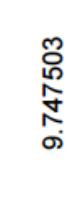 & $\begin{array}{l}\text { ָ̃ } \\
\text { స్ } \\
\text { Oे }\end{array}$ & $\begin{array}{l}\stackrel{\infty}{\infty} \\
\stackrel{\infty}{\infty} \\
\stackrel{్}{్} \\
\stackrel{\sim}{+}\end{array}$ & $\begin{array}{l}\text { 足 } \\
\text { m. } \\
\stackrel{0}{0} \\
0\end{array}$ & 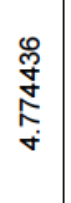 & $\begin{array}{l}\frac{2}{2} \\
0 \\
0 \\
0 \\
0\end{array}$ & 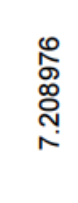 & 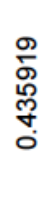 & 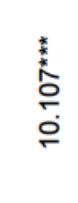 & 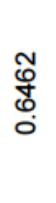 & 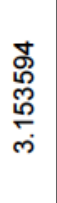 & 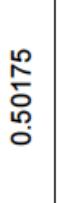 & 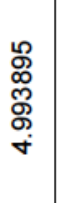 & 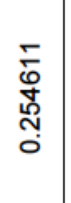 & $\begin{array}{l}\bar{S} \\
\text { ND } \\
i \\
\infty \\
\infty\end{array}$ & 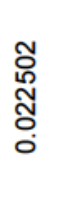 \\
\hline 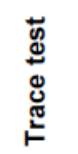 & $\frac{\bar{N}}{\underset{J}{J}}$ & 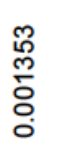 & 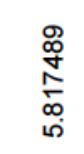 & 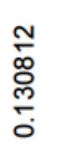 & 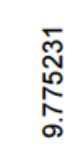 & 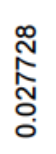 & 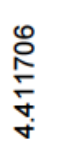 & 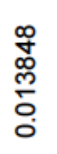 & 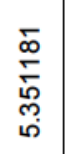 & \begin{tabular}{l}
0 \\
\multirow{0}{0}{} \\
0 \\
0 \\
0 \\
0
\end{tabular} & 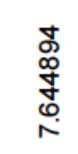 & 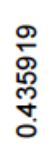 & 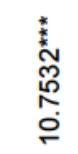 & 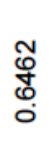 & 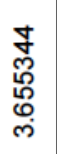 & 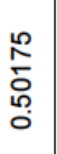 & 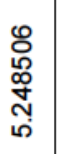 & 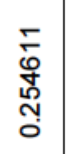 & 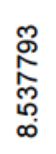 & 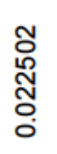 \\
\hline 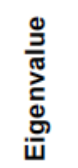 & 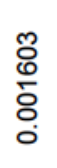 & 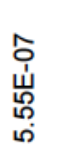 & 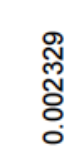 & 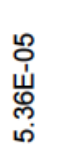 & $\begin{array}{l}\stackrel{\circ}{0} \\
\text { o } \\
\text { ర్ } \\
0 \\
0\end{array}$ & 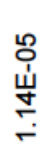 & 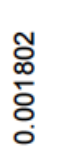 & 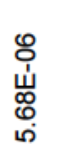 & $\begin{array}{l}\stackrel{0}{\circ} \\
\stackrel{\leftrightarrow}{\circ} \\
\vdots \\
0\end{array}$ & 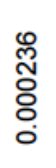 & 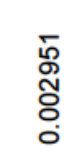 & $\begin{array}{l}\frac{9}{2} \\
\stackrel{0}{\circ} \\
\stackrel{0}{0}\end{array}$ & $\begin{array}{l}\stackrel{m}{\tilde{m}} \\
\dot{\delta} \\
\stackrel{0}{0}\end{array}$ & 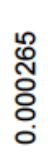 & 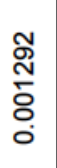 & $\begin{array}{l}\mathscr{N} \\
\text { ठे } \\
\text { ठ } \\
\circ\end{array}$ & $\begin{array}{l}\text { ஜ } \\
\text { సิ } \\
\text { ơ } \\
0\end{array}$ & $\begin{array}{l}\text { 음 } \\
\frac{0}{0} \\
0 \\
0\end{array}$ & 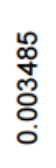 & 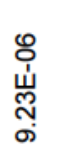 \\
\hline 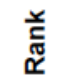 & I & $\underset{\underline{\pi}}{\underline{\pi}}$ & IU & $\underline{\underline{\pi}}$ & II & $\underline{\underline{\pi}}$ & i & ָָ & i & $\underline{\underline{\pi}}$ & i & $\underset{\underline{\pi}}{\underline{\pi}}$ & i & $\underline{\underline{I}}$ & iㅛ & $\underset{\underline{\pi}}{\underline{\pi}}$ & i & II & i & $\underline{\bar{\pi}}$ \\
\hline 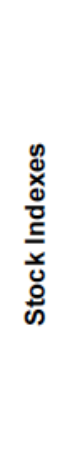 & 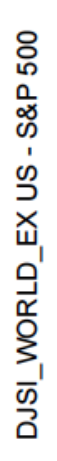 & & 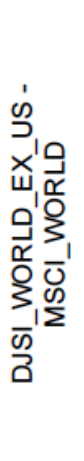 & & 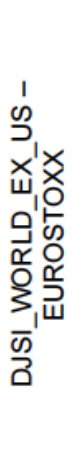 & & 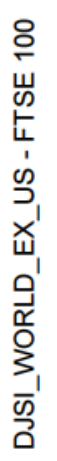 & & $\begin{array}{l}0 \\
0 \\
0 \\
0 \\
\infty \\
\infty \\
1 \\
5 \\
D^{\prime} \\
\infty \\
x_{1} \\
5 \\
w \\
w\end{array}$ & & 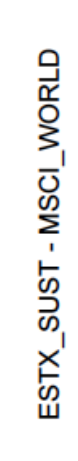 & & 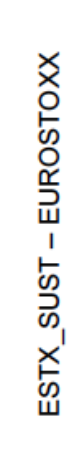 & & 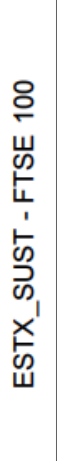 & & 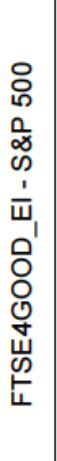 & & 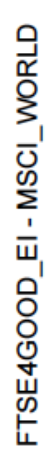 & \\
\hline 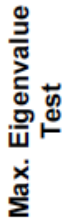 & 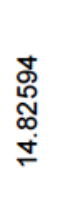 & 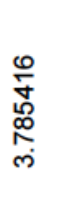 & 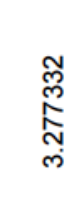 & 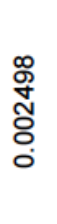 & 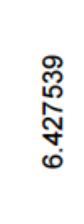 & 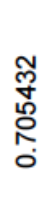 & 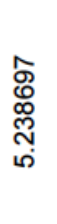 & 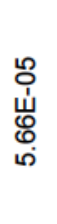 & 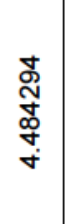 & $\begin{array}{l}\mathscr{0} \\
\mathbb{0} \\
\stackrel{\overbrace ్}{0} \\
\stackrel{0}{0}\end{array}$ & 总 & 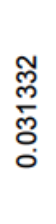 & 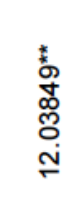 & $\begin{array}{l}\mathscr{N} \\
\mathbb{N} \\
\mathscr{0} \\
0 \\
0\end{array}$ & 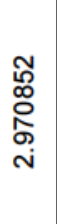 & $\begin{array}{l}\mathscr{0} \\
\mathscr{0} \\
0 \\
0 \\
0 \\
0\end{array}$ & 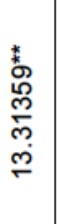 & 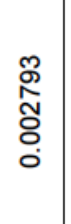 & 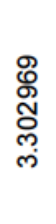 & 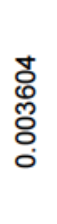 \\
\hline 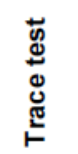 & $\frac{\stackrel{\infty}{\infty}}{\stackrel{\infty}{\infty}} \underset{\infty}{\infty}$ & 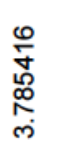 & 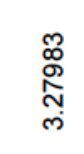 & 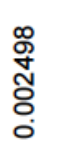 & $\begin{array}{l}\bar{N} \\
\stackrel{N}{N} \\
\stackrel{N}{N}\end{array}$ & 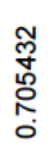 & 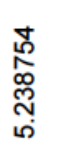 & 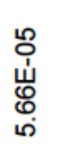 & 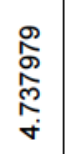 & 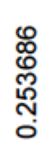 & 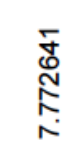 & 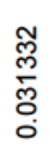 & 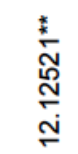 & $\begin{array}{l}\mathscr{N} \\
\underset{\mathbb{N}}{0} \\
\mathbb{0} \\
0 \\
0\end{array}$ & 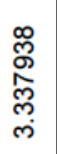 & 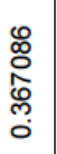 & 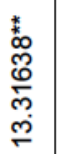 & 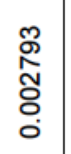 & 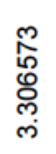 & 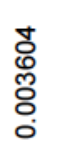 \\
\hline 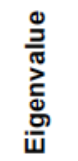 & $\begin{array}{l}\& \\
\& \\
0\end{array}$ & $\begin{array}{l}\overline{5} \\
\stackrel{5}{\circ} \\
\vdots \\
0 \\
0\end{array}$ & $\frac{\text { m}}{\stackrel{m}{\circ}}$ & 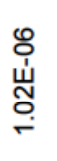 & 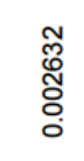 & 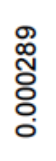 & 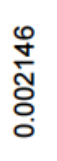 & 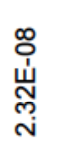 & $\begin{array}{l}\hat{\infty} \\
\infty \\
\infty \\
0 \\
0\end{array}$ & $\begin{array}{l}\text { 뭉 } \\
\text { 웅 }\end{array}$ & 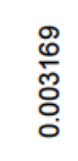 & 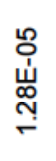 & 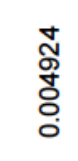 & 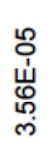 & $\begin{array}{l}\hat{N} \\
\stackrel{N}{0} \\
\stackrel{0}{0}\end{array}$ & $\begin{array}{l}\text { مீ } \\
\stackrel{0}{0} \\
0\end{array}$ & $\begin{array}{l}\text { 导 } \\
\text { 号 } \\
\text { O. }\end{array}$ & 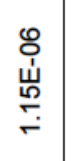 & $\begin{array}{l}\stackrel{0}{0} \\
\stackrel{m}{0} \\
\stackrel{0}{0}\end{array}$ & 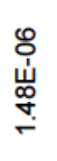 \\
\hline 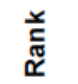 & i & $\underset{\underline{\pi}}{\pi}$ & $\stackrel{i}{L}$ & $\underline{\underline{\pi}}$ & II & $\underset{\underline{\pi}}{\underline{\pi}}$ & II & $\underset{\underline{\pi}}{\bar{x}}$ & iI & $\underset{\underline{v}}{\bar{v}}$ & i & $\underline{\underline{\pi}}$ & II & $\underline{\underline{\pi}}$ & II & $\underset{\underline{\pi}}{\pi}$ & i & $\underline{\pi}$ & III & $\underline{\underline{\pi}}$ \\
\hline 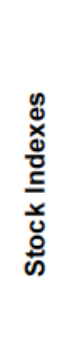 & 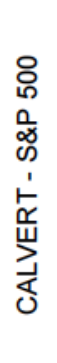 & & 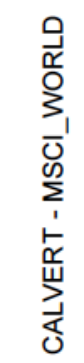 & & 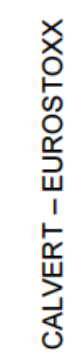 & & 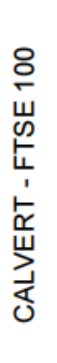 & & 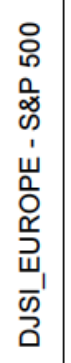 & & 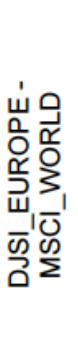 & & 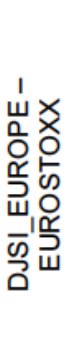 & & 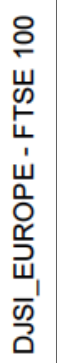 & & 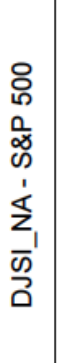 & & 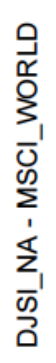 & \\
\hline
\end{tabular}




\begin{tabular}{|c|c|c|c|c|c|c|c|c|c|c|c|c|c|c|c|c|c|c|c|c|}
\hline 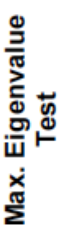 & 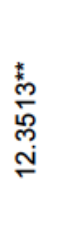 & $\frac{\stackrel{\infty}{\Delta}}{\stackrel{d}{d}}$ & 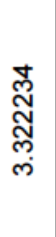 & 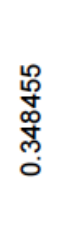 & 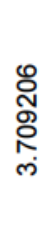 & $\begin{array}{l}\bar{o} \\
\bar{\delta} \\
\stackrel{0}{0} \\
0\end{array}$ & 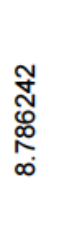 & 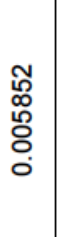 & 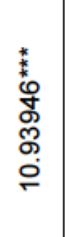 & 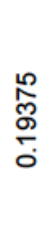 & $\begin{array}{l}\text { oे } \\
0 \\
0 \\
\infty \\
\infty \\
\text { ల. }\end{array}$ & $\begin{array}{l}\mathscr{0} \\
0 \\
0 \\
0 \\
0 \\
0\end{array}$ & 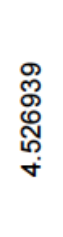 & $\begin{array}{l}\infty \\
\vdots \\
\swarrow \\
\varnothing \\
0\end{array}$ & 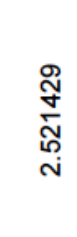 & $\begin{array}{l}\text { \% } \\
\text { ष̊ } \\
0\end{array}$ & $\begin{array}{l}0 \\
0 \\
0 \\
0 \\
\infty \\
\omega\end{array}$ & & 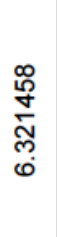 & 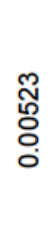 \\
\hline 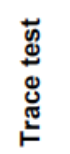 & 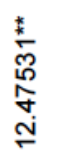 & 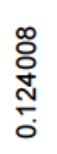 & $\begin{array}{l}\mathbb{8} \\
0 \\
0 \\
0 \\
0 \\
\tilde{j}\end{array}$ & 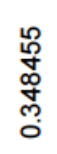 & 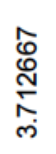 & 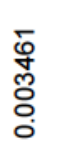 & 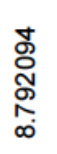 & 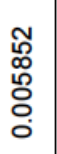 & 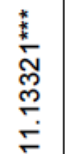 & $\begin{array}{l}\frac{\infty}{人} \\
\stackrel{0}{0} \\
\frac{0}{0}\end{array}$ & 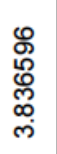 & $\begin{array}{l}\mathscr{0} \\
\stackrel{0}{0} \\
0 \\
0 \\
0\end{array}$ & $\begin{array}{l}\text { 芯 } \\
\stackrel{N}{0} \\
\stackrel{\leftrightarrow}{0}\end{array}$ & $\begin{array}{l}\infty \\
\overleftarrow{0} \\
\mathscr{0} \\
0 \\
0\end{array}$ & 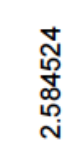 & 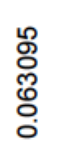 & $\begin{array}{l}\text { ڤ్ } \\
\text { స్ల } \\
\end{array}$ & & $\begin{array}{l}\infty \\
\& \\
\& \\
\mathbb{N} \\
0\end{array}$ & 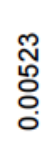 \\
\hline 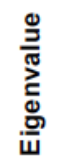 & $\begin{array}{l}\overline{0} \\
\text { Oొ } \\
0 \\
0 \\
0\end{array}$ & 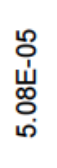 & $\begin{array}{l}\bar{o} \\
\bar{m} \\
\bar{\delta} \\
0\end{array}$ & 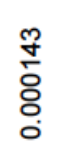 & 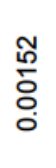 & 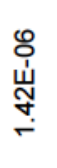 & 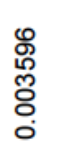 & 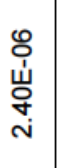 & 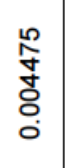 & 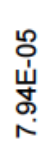 & $\begin{array}{l}\frac{N}{6} \\
\frac{5}{8} \\
0\end{array}$ & 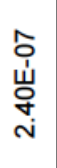 & 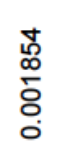 & 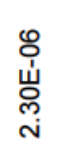 & 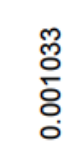 & 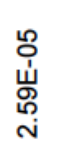 & 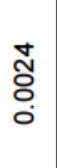 & $\begin{array}{l}\text { ஜ్ల్ } \\
\text { ర్ } \\
\text { ర } \\
\text { ○ }\end{array}$ & 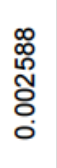 & 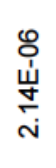 \\
\hline 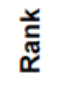 & $\stackrel{0}{1}$ & ָi & $\mathbb{L}$ & II & $\stackrel{0}{\mathbb{1}}$ & $\underline{\underline{\pi}}$ & $\stackrel{0}{\Perp}$ & $\underline{\underline{x}}$ & $\ddot{L}$ & $\underset{\underline{\pi}}{\bar{u}}$ & $\mathbb{I}$ & $\underline{\underline{\pi}}$ & $\stackrel{0}{\mathbb{L}}$ & $\underline{\underline{\pi}}$ & II & $\begin{array}{l}\bar{\pi} \\
\underline{v}\end{array}$ & $\ddot{\mathbb{L}}$ & $\underline{\bar{\pi}}$ & $\ddot{\mathbb{L}}$ & $\begin{array}{l}\bar{\pi} \\
\underline{v}\end{array}$ \\
\hline 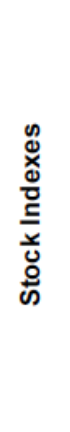 & 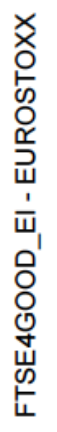 & & 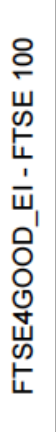 & & 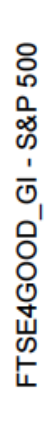 & & 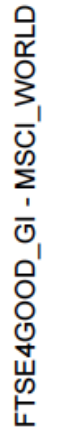 & & 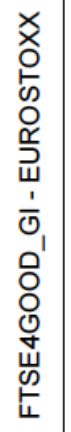 & & 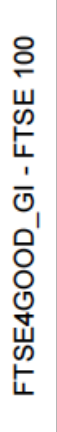 & & 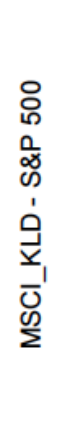 & & 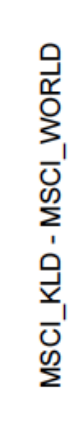 & & 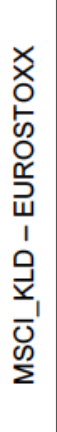 & & 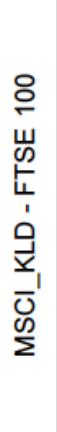 & \\
\hline 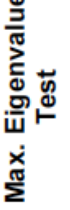 & $\begin{array}{l}\overline{0} \\
\stackrel{0}{0} \\
0 \\
\dot{0}\end{array}$ & $\begin{array}{l}\stackrel{N}{J} \\
\text { ల్ల } \\
\stackrel{0}{0}\end{array}$ & 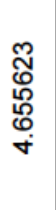 & $\begin{array}{l}\frac{0}{0} \\
\text { চे } \\
\dot{0}\end{array}$ & 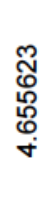 & $\begin{array}{l}\frac{\mathscr{T}}{\square} \\
\frac{8}{0} \\
\dot{0}\end{array}$ & 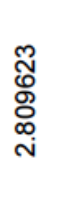 & 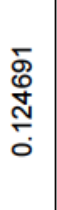 & 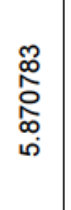 & $\frac{5}{\stackrel{2}{0}}$ & 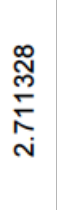 & $\begin{array}{l}\text { o. } \\
\text { o. } \\
\stackrel{m}{0} \\
\text { c. }\end{array}$ & 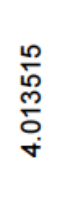 & $\begin{array}{l}\hat{\sigma} \\
\overline{0} \\
\text { o }\end{array}$ & 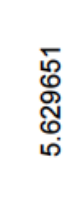 & 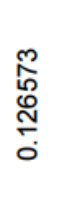 & $\begin{array}{l}\mathscr{0} \\
\frac{0}{\infty} \\
\frac{\infty}{N} \\
\infty\end{array}$ & $\frac{\stackrel{\hat{m}}{\frac{\sigma}{\sigma}}}{\stackrel{0}{\circ}}$ & \begin{tabular}{l} 
怘 \\
0 \\
\multirow{0}{*}{} \\
$\dot{\sigma}$
\end{tabular} & 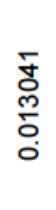 \\
\hline 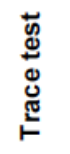 & 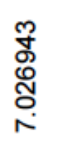 & 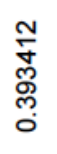 & 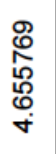 & $\begin{array}{l}\frac{0}{\circ} \\
\stackrel{0}{0} \\
0 \\
0\end{array}$ & $\begin{array}{l}\stackrel{8}{0} \\
\stackrel{0}{0} \\
0 \\
\stackrel{+}{+} \\
\end{array}$ & $\begin{array}{l}\frac{0}{\circ} \\
\frac{0}{0} \\
0 \\
\circ\end{array}$ & 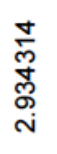 & 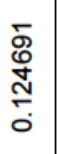 & $\begin{array}{l}\mathbb{2} \\
\infty \\
\infty \\
\stackrel{0}{0} \\
\dot{0}\end{array}$ & $\frac{5}{\frac{0}{0}}$ & 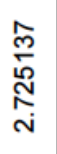 & 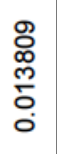 & $\begin{array}{l}\mathscr{2} \\
\stackrel{0}{0} \\
\stackrel{\omega}{\circ} \\
\dot{+}\end{array}$ & के & 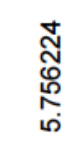 & 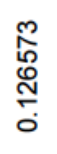 & 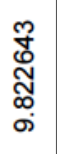 & $\begin{array}{l}\stackrel{\hat{m}}{\frac{\sigma}{0}} \\
\stackrel{0}{0}\end{array}$ & $\begin{array}{l}\mathscr{D} \\
\mathscr{D} \\
\stackrel{N}{N} \\
\dot{+}\end{array}$ & $\begin{array}{l}\bar{\delta} \\
\text { - } \\
\dot{0} \\
\dot{0}\end{array}$ \\
\hline 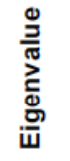 & $\begin{array}{l}\stackrel{0}{\hat{N}} \\
\text { స్ } \\
\stackrel{0}{0}\end{array}$ & $\begin{array}{l}\overline{0} \\
\overline{0} \\
0 \\
0\end{array}$ & 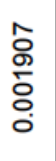 & 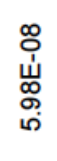 & 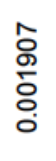 & 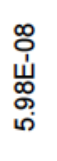 & $\begin{array}{l}\frac{5}{5} \\
\frac{0}{0} \\
0 \\
0\end{array}$ & 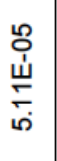 & 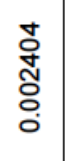 & 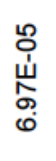 & $\begin{array}{l}\frac{\tau}{c} \\
\overline{0} \\
0 \\
0\end{array}$ & 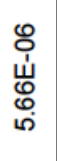 & $\begin{array}{l}\text { J } \\
\vdots \\
\circ \\
0\end{array}$ & $\begin{array}{l}\hat{0} \\
\dot{u} \\
\stackrel{\omega}{0} \\
\infty \\
\infty\end{array}$ & 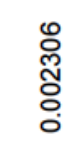 & 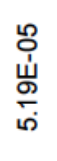 & $\begin{array}{l}\text { ণ } \\
\text { Oे } \\
\text { षे } \\
\text { ठ }\end{array}$ & 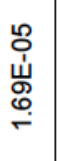 & $\begin{array}{l}\text { N్ } \\
\stackrel{\sigma}{\circ} \\
0 \\
\end{array}$ & 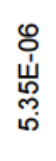 \\
\hline 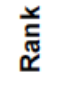 & II & ָָ & $\stackrel{0}{1}$ & $\underline{\underline{\pi}}$ & 표 & $\underline{\bar{u}}$ & III & ָָ & II & $\underline{\underline{\pi}}$ & ï & $\underline{\bar{v}}$ & II & ָָ & iㅛ & $\underline{\underline{v}}$ & $\ddot{\mathbb{1}}$ & $\underline{\pi}$ & II & $\underset{\text { II }}{\bar{v}}$ \\
\hline 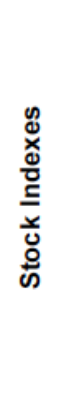 & 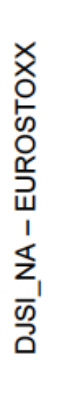 & & 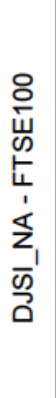 & & 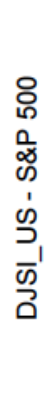 & & 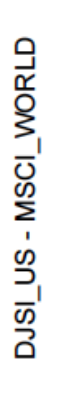 & & 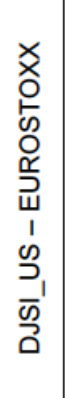 & & 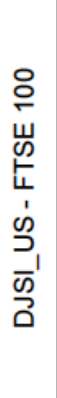 & & 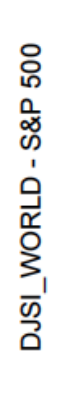 & & 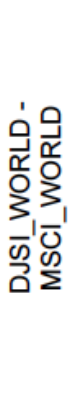 & & 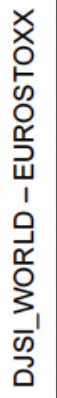 & & 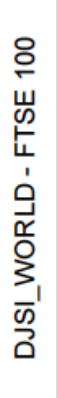 & \\
\hline
\end{tabular}


indexes. As stated by Engle and Granger (1987) nonstationary time series are said to be cointegrated if there is a linear stationary combination of two or more nonstationary series, named cointegration equation, and may be interpreted as a long-run relationship among series.

If stock indexes cointegration is proven, then we can expect that in the long run both traditional and sustainable stock indexes will follow the same trend, which means that prices will not move 'too far away' from each other.

Since all stock indexes series are non-stationary and integrated of order 1(as we conclude through ADF and KPSS tests) cointegration analysis is the appropriate tool for investigating the relationships between each sustainable stock index and the traditional stock indexes under analysis. Thus, we proceed to the bivariate cointegration analysis by using the Johansen cointegration test. Both trace and maximum eigen value statistics are computed.

At a $10 \%$ significance level (Table 12), both trace and maximum eigenvalue statistics fail to reject the null of no-cointegration in the majority of cases (35 of the 40 pairs of stock indexes). According to the tests, the 5 pairs of stock indexes that are cointegrated are: DJSI Europe and EURO STOXX, DJSI North America and S\&P 500, EURO STOXX Sustainability and EURO STOXX, FTSE4Good Europe and EURO STOXX and FTSE4Good Global and EURO STOXX. Consequently, we just can expect long-run relationships between these 5 pairs of stock indexes.

Hence, at a $10 \%$ significance level, it is possible to conclude that the results from the cointegration analysis indicate that there are no long-run relationships between most of sustainable and traditional stock indexes. Moreover, at a $1 \%$ significance level, no cointegration between stock indexes was detected. Thus, as noticed before through the Granger causality test, only short-term dependence is observed. This lack of cointegration suggests that stock indexes have no long-run linkage and sustainable and traditional stock indexes can diverge without bound. Due to this fact, no VEC models were estimated.

\section{CONCLUDING REMARKS}

There is a long-standing debate on the link between socially responsible investment (SRI) strategies and investor's portfolio performance, however this is not a consensual matter. While some authors provide evidences on the financial and social benefits of responsible strategies, others argue that it can be a destructive factor of shareholders value.

This study aims to provide evidence about the link between SRI and investor's financial performance and the long term value creation of such strategies. With this purpose 3 main objectives were established to investigate under this paper. (1) To compare the performance of the traditional stock indexes against the performance of the sustainable stock indexes. (2) To analyze whether sustainable stock indexes returns are caused by traditional stock indexes returns, and vice versa. (3) To capture long run common trends between the behavior of traditional and sustainable stock indexes.

To address these questions, daily prices and returns of 4 traditional and 10 sustainable stock indexes were collected from 2001 to 2011 and a variety of tests were conducted. The range of traditional stock indexes encompasses: EURO STOXX, FTSE 100, S\&P 500 and MSCI World; while the set of sustainable stock indexes is composed by: EURO STOXX Sustainability, FTSE4Good Europe Index, FTSE4Good Global Index, DJSI Europe, DJSI World, DJSI World excluding US, DJSI US, DJSI North America, Calvert Social Index and MSCI KLD 400 Social Index.

To serve the first objective of this study, both parametric and non-parametric tests were used to compare the financial performance of the traditional and sustainable stock indexes. Results pointed that sustainable stock indexes outperformed traditional stock indexes in all periods under analysis; however the differences on average daily returns are not statistically significant.

Then, to answer the second question of this paper, Granger causality test were conducted to capture short term relationships between traditional and sustainable stock indexes returns. It was observed that there is a feedback effect between traditional and sustainable stock indexes returns. Hence, it is possible to conclude that most of the traditional stock indexes return influence sustainable stock indexes returns, as well as that the majority of the sustainable indexes returns also cause traditional stock indexes returns.

To capture long term common trends between the behavior of the traditional and sustainable stock 
indexes cointegration analysis was carried out. Thus, long-run relationship analysis pointed that most of the stock indexes are not cointegrated, suggesting that sustainable and traditional stock indexes do not have a long-run linkage and can diverge without bound.

In fact, results achieved in this study are very in line with the overall conclusions of the literature review. As in most of the previous studies, this investigation point to a neutral relationship between SRI and portfolio returns. However, results are not directly comparable once in this study we employ different statistical tests.

\section{REFERENCES}

Abramson, L. and D. Chung. 2000. "Socially responsible investing: Viable for value investors?". Journal of Investing 9(3):73-80. http://dx.doi.org/10.3905/joi.2000.319381

Bauer, R., R. Otten, and A. Rad. 2006. "Ethical investing in Australia: Is there a financial penalty?". Pacific-Basin Finance Journal 14(1):33-48. http://dx.doi.org/10.1016/j.pacfin.2004.12.004

Benson, K.L., T.J. Brailsford, and J. E. Humphrey. 2006. "Do socially responsible fund managers really invest differently?" Journal of Business Ethics 65(4):337-357. http://dx.doi.org/10.1007/s10551-006-0003-8

Box, G. E. P., and G.M. Jenkins. 1970. "Time Series Analysis: Forecasting and Control. San Francisco: Holden Day.

Chong, J., M. Her, and G.M. Phillips. 2006. "To sin or not to $\sin$ ? Now that's the question." Journal of Asset Management 6(6): 406417. http://dx.doi.org/10.1057/palgrave.jam.2240191

Cortez, M. C., F. Silva, and N. Areal. 2009. "The performance of European socially responsible funds."http://www.ifkcfs.de/fileadmin/downloads/events/conferences/2008Asset_Cortez_Silva_Areal.pdf

Curran, M.M. and D.Moran. 2007. "Impact of the FTSE4 Good Index on firm price: an event study." Journal of Environmental Management 82:529-537. http://dx.doi.org/10.1016/j.jenvman.2006.02.010

Derwall, J., N. Guenster, R. Bauer, and K.Koedijk. 2005. "The ecoefficiency premium puzzle." Financial Analysts Journal 61(2):51-63. http://dx.doi.org/10.2469/faj.v61.n2.2716

Dickey, D.A., and W:A Fuller. 1981. "Likelihood Ratio Statistics for autoregressive Time Series with a Unit Root." Econometrica 49:1057-1072.

http://dx.doi.org/10.2307/1912517

Elsayed, K. and D. Paton. 2004. "The impact of environmental performance on firm performance: static and dynamic panel data evidence." Structural Change and Economic Dynamics 16:395-412.

http://dx.doi.org/10.1016/j.strueco.2004.04.004

Engle, R.F., and C.W.J Granger. 1987. "Co-integration and error correction. Representation, estimation and testing." Econometrica 55:251-276. http://dx.doi.org/10.2307/1913236

European Sustainable Investment Forum -Eurosif.2010.“European SRI Study 2010." http://www.eurosif.org/research/eurosif-sristudy/2010

European Sustainable Investment Forum -Eurosif.2008."High Net Worth Individuals (HNWI) and Sustainable Investment 2008." http://www.eurosif.org/research/hnwi-a-sustainableinvestment/2008
Fama, E., and K. French, 1992. "The cross section of expected stock returns." Journal of Finance 47(2): 427-465. http://dx.doi.org/10.1111/j.1540-6261.1992.tb04398.x

Gompers, P., J. Ishii, and A. Metrick.2003.“Corporate governance and equity prices." The Quarterly Journal of Economics 118(1):107-155. http://dx.doi.org/10.1162/00335530360535162

Granger, C.W.J. 1969. "Investigating causal relations by econometric models and cross-spectral methods." Econometrica 37:424438.

http://dx.doi.org/10.2307/1912791

Granger, C.W.J. and P. Newbold. 1974. "Spurious regressions in econometrics." Journal of Econometrics 2:111-120. http://dx.doi.org/10.1016/0304-4076(74)90034-7

Hair, J. F., W.C. Black, B. J. Babin, and R.E. Anderson. 2009. Multivariate data analysis (7th ed.). Upper Saddle River, NJ: Prentice Hall.

Hill, R. P., T. Ainscough, T. Shank, and M. Manullang. 2006. "Corporate Social Responsibility and Socially Responsible Investing: A Global Perspective". Journal of Business Ethics 70:165-174. http://dx.doi.org/10.1007/s10551-006-9103-8

Hong, H. and M. Kacperczyk. 2009. "The Price of Sin: The Effects of Social Norms on Markets." http://pages.stern.nyu.edu/ $\sim$ sternfin/mkacperc/public_html/sin.pdf

Hume, S. R. and A. Larkin. 2008. "The Performance of Socially Responsible Investing." http://www.crrconference.org/ downloads/humelarkin.pdf

Johansen, S., K. Juselius. 1990. "Maximum Likelihood estimation and inference on cointegration - with applications to the demand for money." Oxford Bulletin of Economics \& Statistics 52:169-210.

http://dx.doi.org/10.1111/j.1468-0084.1990.mp52002003.x

Johansen, S. 1991. "Estimation and hypothesis testing of cointegration vectors in Gaussian autoregressive models." Econometrica 59:1551-1580. http://dx.doi.org/10.2307/2938278

Johansen, S. 1995. Likelihood-based inference in Cointegrated Vector Autoregressive Models. Oxford University Press. http://dx.doi.org/10.1093/0198774508.001.0001

Lombardo, R. and G. D'Orio. 2012. "Corporate and state social responsibility: a long term perspective." Modern Economy 3: 91-99. http://dx.doi.org/10.4236/me.2012.31013

López, M.V., A. Garcia, and L. Rodriguez. 2007."Sustainable development and corporate performance: A study based on the Dow Jones Sustainability Index." Journal of Business Ethics 75:285-300. http://dx.doi.org/10.1007/s10551-006-9253-8

Louche, C. 2004. "Ethical Investment Processes and mechanisms of institutionalisation in the Netherlands 1990-2002." PhD dissertation, Erasmus University Rotterdam.

King, A., and M. Lenox. 2001. "Does it really pay to be green? An empirical study of firm environmental and financial performance." Journal of Industrial Ecology 5(1): 105-116. http://dx.doi.org/10.1162/108819801753358526

Kwaitowski, D., P. Phillips, P. Schmidt, and Y. Shin. 1992. "Testing the null hypothesis of stationarity against the null hypothesis of a unit root." Journal of Econometrics 54:159-78. http://dx.doi.org/10.1016/0304-4076(92)90104-Y

KPMG. 2011."Sustainable Insight: articulating the value of sustainability to mainstream investors." http://www.csreurope. org/data/files/For_news/Sustainable_Insight_Jan_2011_2.pdf

Machado, M.R.M.A.V. Machado, and L.J. Corrar. 2009. "Managerial Sustainability Index (ISE) Performance of São Paulo Stock Exchange." Revista Universo Contábil 5(2):24-38. http://dx.doi.org/10.4270/ruc.2009211 
Maddala, G. S. and I.-M. Kim. 2000. "Unit roots, cointegration and structural change." United Kingdom: Cambridge University Press.

Opler, T.C. and J. Sokobin. 1995. "Does coordinated institutional activism work? An analysis of the activities of the Council of Institutional Investors." Working paper, Ohio State University.

Orlitzky, M., F.L. Schmidt, and S.L. Rynes. 2003. "Corporate social and financial performance: A meta-analysis." Organization Studies 24(3): 403-441. http://dx.doi.org/10.1177/0170840603024003910

Phillips, P.C.B. 1986. "Understanding spurious regressions in econometrics." Journal of Econometrics 33: 311-340. http://dx.doi.org/10.1016/0304-4076(86)90001-1

Schröder, M. 2004. "The performance of socially responsible investments: Investment funds and indices." Financial Markets and Portfolio Management 18(2):122-142. http://dx.doi.org/10.1007/s11408-004-0202-1

Shank, T. M., D.K. Manullang, and R.P. Hill. 2005. "Is it better to be naughty or nice?" Journal of Investing 14(3):82-87. http://dx.doi.org/10.3905/joi.2005.580553

Social Investment Forum - SIF.2010."Report on Socially Responsible Investing Trends in the United States 2010."http://www.socialinvest.org/resources/pubs/trends/doc uments/2010TrendsES.pdf
Statman, M. 2000. "Socially responsible mutual funds." Financial Analysts Journal 56(3):30-39. http://dx.doi.org/10.2469/faj.v56.n3.2358

Statman, M. 2006. "Socially responsible indexes: Composition, performance, and tracking error." The Journal of Portfolio Management 32(3):100-109. http://dx.doi.org/10.3905/jpm.2006.628411

Statman, M. and d. Glushkov.2008."The wages of social responsibility." http://www.socialinvest.org/resources/ research/documents/2008WinningPrize-Moskowitz.pdf

Stenström, H. C. and J.J. Thorell. 2007. "Evaluating the Performance of Socially Responsible Investment Funds: A Holding Data Analysis." MScin Finance, Stockholm School of Economics.

Velde, E., W. Vermeir. and F. Corten. 2005. "Corporate social responsibility and financial performance." Corporate Governance 5(3):129-138. http://dx.doi.org/10.1108/14720700510604760

Ziegler, A., M. Schröder, and K. Rennings. 2007. "The Effect of environmental and social performance on the stock performance of European corporations." Environmental and Resource Economics 37:661- 680. http://dx.doi.org/10.1007/s10640-007-9082-y

DOI: http://dx.doi.org/10.6000/1929-7092.2014.03.26

(C) 2014 Curto and Vital; Licensee Lifescience Global.

This is an open access article licensed under the terms of the Creative Commons Attribution Non-Commercial License (http://creativecommons.org/licenses/by-nc/3.0/) which permits unrestricted, non-commercial use, distribution and reproduction in any medium, provided the work is properly cited. 